\title{
The Ottoman fortress above Skradin in Dalmatia
}

\author{
Josip Pavić \\ Public Cultural Institution “Fortress of Culture”, Šibenik, Croatia, josip@tvrdjava-kulture.hr
}

\begin{abstract}
Skradin is a town on the right bank of the Krka river, about $15 \mathrm{~km}$ upstream from Šibenik. Located deep in the hinterland, with good road connections, and a luxury of natural resources nearby, it's no wonder that urban life flourished here since the Iron Age. But being below surrounding hills, this trading centre could never be successfully defended from a prolonged siege. This is why, throughout medieval times, Skradin was usually regarded as a less important neighbour of flourishing Šibenik. Various Croatian noble families, and occasionally the Venetians, ruled the town in fifteenth century. Conquered by the Ottomans in winter of 1521-22, Skradin soon again became an important trading point, the southernmost town in Krka sancak. It was reclaimed by Venetians temporarily from 1647 to 1670, and permanently from 1683. Today, due to the thorough destruction by the Venetian army, the earliest buildings in Skradin date to eighteenth century. The one exception is Turina, a small late medieval fort above the town. Recently branded as a fortress of Šubić family -the powerful magnates from late thirteenth century-, Turina was long considered to be Skradin's main defensive point even in the Ottoman era. However, several archival sources suggested the existence of another fort, located on a much more favourable position. This theory was finally confirmed by surveying the nearby Gradina hill in the autumn of 2018.
\end{abstract}

Keywords: Dalmatia, Skradin, Ottomans, Venice.

\section{About Skradin}

Two millennia ago, Roman authorities in Dalmatia were generally taking over earlier protourban structures, adjusting them slightly to their needs. The existence of transportation routes was essential for their state operations, because they enabled a quick and efficient administration, trade and military movements. Therefore, it is not surprising that their three initial urban centres and first juridical convents of Dalmatia were three very favourable pre-Roman harbours, located on river mouths and recessed into land as deep as possible -Scardona, Salona and Narona-.

The northernmost of them was Scardona, the name of which is of Illyrian origin. The Roman city, like the one of today, is located on the right bank of Krka, at the place where the river is flowing into its submerged valley (ria). The small town is on a small peninsula between Rokovača cove (once a Roman port) and the valley of a creek called Rivina Jaruga, which leads to a very large and fertile area upstream. This location can be very advantageous in peacetime, as trading and urban centre, but being surrounded with higher hills, it cannot be successfully defended from serious or prolonged attacks. Skradin thus thrived within the orderly first couple of Roman centuries, and then again almost a thousand years later during the magnate para-state of Šubić family, when it was one of their capitals and the main port of the entire unified Dalmatian hinterland (Karbić, 2004). But throughout the medieval era, this area was dominated by nearby city of Šibenik, which had -unlike Skradin- suc- 
ceeded in developing permanent political, economic and societal structures typical for the communal era.

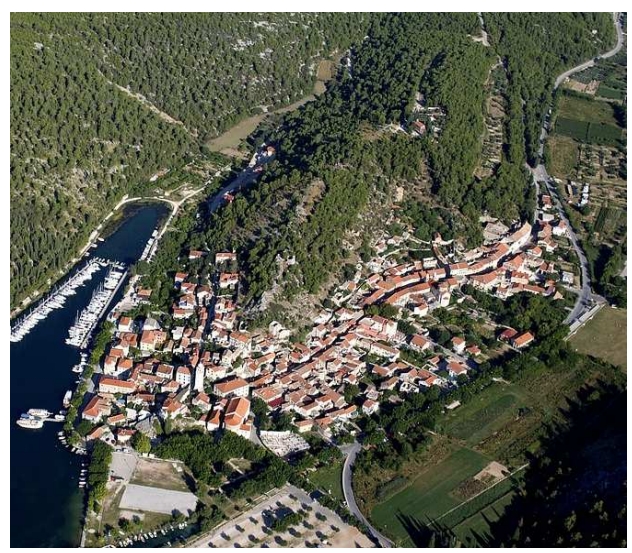

Fig. 1. Aerial view of Skradin from the south.

By the described pattern, the importance of Skradin waned in the uneasy fifteenth century, with constant conflicts all over Dalmatia between Croatian noblemen and the Republic of Venice. This is also the era of the first Ottoman raids. At the end of this century, Skradin is ruled by the Kings of Hungary, although Venice had repeatedly considered its occupation in order to mount a stronger guard from akınci and martolos troops. The defence of Dalmatian hinterland had finally collapsed in the winter and spring of 1522, with the entering of Ottoman frontiersmen in Knin and Skradin without almost any resistance.

\section{Skradin under the Ottoman rule}

The Ottoman government was formed in a short time, and Skradin became a seat of qadi and one of the main administrative and military centres of Klis, and later Krka sancak (Spaho, Aličić, 2007). As the river Krka was not navigable upstream from Skradin, and the mouth was controlled by Venetians, the town remained very vulnerable to naval attack, and the Ottomans never succeeded in establishing a shipyard or harbour there. Venetian galleys attacked and razed Skradin in the wars of 1537-40 and 157073 , but did not establish permanent occupation, confirming once more the difficulties of arranging the town's defence. In 1553, the Venetian sindico Giustiniani writes that Skradin is a ruin governed by Turks, all because of the carelessness (poca cura) of Venetian commanders in the last war (CRV, tom. II, 1877, p. 199). The town has several wooden houses, and newer walls but badly made, about $700 \mathrm{~m}$ long, in triangular form. Three city gates, the middle ones being on a rocky mound, are protected by three Turkish squadrons, but overall Skradin is not strongly defended and could be taken with just a few galleys. During the next war, in late 1570 or 1571 , G. Camocio made his well-known veduta published in the issues of his travelogue Viaggi $d a$ Venezia a Constantinopoli per mare e per terra (Slukan Altić, 2007, p. 159).

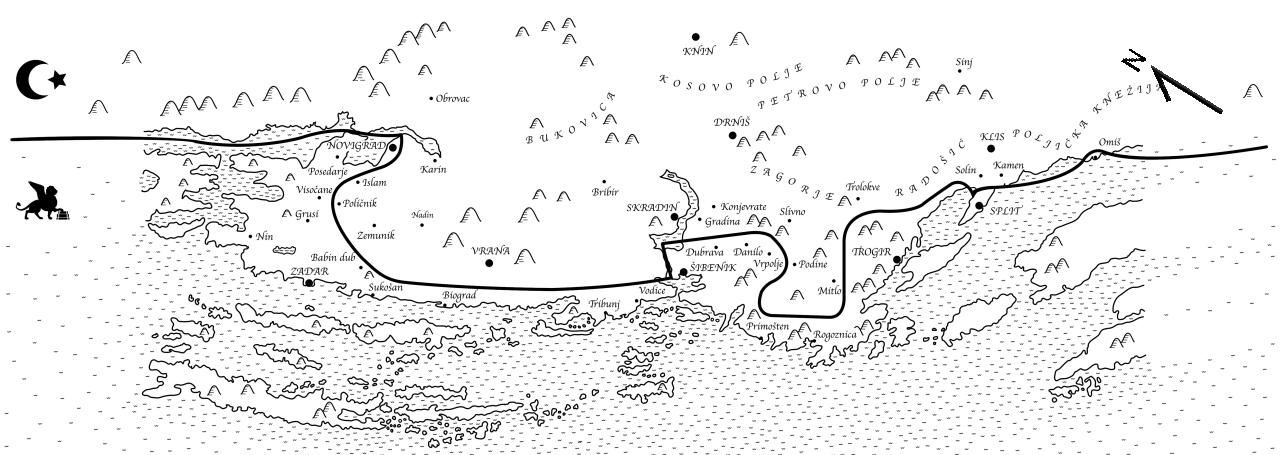

Fig. 2. Dalmatian coast between Zadar and Omiš, with border between the Ottomans and Venice from 1573 to 1645 marked in black. Notice the unfavorable "coastal" position of Skradin (Kazinoti, Komenda, 2019). 
However, an extended peacetime after these two Venetian-Ottoman wars had an initial positive effect to local economy. Archival sources are showing that the new inhabitants of Skradin (both Christians and Muslims) have moderately prospered due to favourable trading and agricultural conditions. The land was divided among the members of military elite, and they, along with some craftsmen, were exempted from certain taxes (Buzov, 2009). All of this is even more evident when reading the reports from the conti et capitani of Venetian Šibenik, with many grievances about the ways that this prosperous marketplace in Skradin is limiting their own trade (CRV, tom. VIII, pp. 194-195).

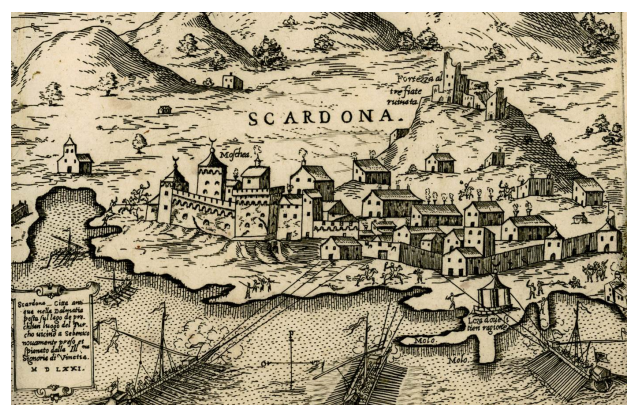

Fig. 3. G. F. Camocio, Scardona, città antiqua nella Dalmazia, 1571, north is up (Šibenik City Museum).

The exhausting War of Crete (1645-69) caused the devastation of Dalmatian hinterland and profound social and economic shifts. In his very successful campaign in early 1647 , the Venetian provveditore generale Lunardo Foscolo (after two earlier failed attempts) conquered Skradin and razed it to the ground (Difnik, 1986). The town was left in ruins until the end of the war, and may have even been additionally destroyed by a later provveditore Dolfin in 1654 . Once again left within the Ottoman state after the demarcation of 1671, Skradin did not manage to recover. Already in late 1683, feeling the effects of the Ottoman defeat at Vienna, the Morlacchi frontiersmen drove out the Muslim inhabitants of Skradin and pillaged the town (Soldo, 1991, p. 132).

\section{Diminished importance}

Skradin was once again, after the expulsion of the Ottoman army and civilians, populated by new inhabitants -Morlacchi people from hinterland, which were led by their leaders, "harambaše" (haramibaşı). The Venetian rule was stabilized by the first decade of eighteenth century, with the new division of the land, formation of administrative structures and the restoration of the old Skradin diocese. The town had remained sparsely populated, because the new population was concentrated around the fertile areas on the outskirts. Almost forcibly, the Venetians formed a separate municipality in 1706 , along with the "nobiliary council" composed of foreign military officers and most powerful harambaša's. By the end of eighteenth century, only 7 council members actually lived in Skradin, and sessions could not be held (Soldo, 1991, pp. 140-147). The commercial activities and connections have mostly been restored, but the town infrastructure was deficient, and the swampy ground and insects led to the spread of disease and "unhealthy air".

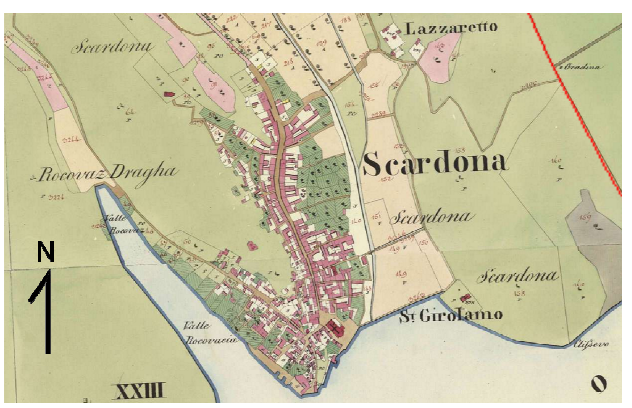

Fig. 4. Cadastral map of Skradin, 1827 (Šibenik City Museum).

Due to these factors, Skradin did not manage to board on the nineteenth century "trains" of industrialization and urbanization, and remained only a local centre of surrounding rural area, just once barely reaching 1000 residents (1961). A new economic activity occurred only in the last few decades, the ever-present tourism of today's Dalmatia. 


\section{Fortifications of Skradin through written and graphic sources}

The remains of a fortification called Turina (archaic Croatian for "tower") are still very prominent on the hill above Skradin. It consists of a round tower and the quasi-bastion on its southeastern side.

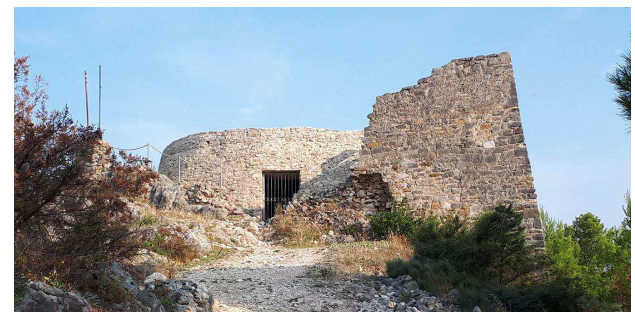

Fig. 5. The remains of Fort Turina today (Sančanin, Suljić, 2018).

Despite many fragments of mortar and stones all over the hill above Skradin, Fort Turina is the sole clearly defined defensive structure within the town. The round tower could be a typical mid-to-late medieval fortification, and is often (although without any precise evidence) connected to the powerful magnate Pavao I. Šubic which governed the area in the second half of thirteenth century. The quasi-bastion is obviously an Early Modern addition.

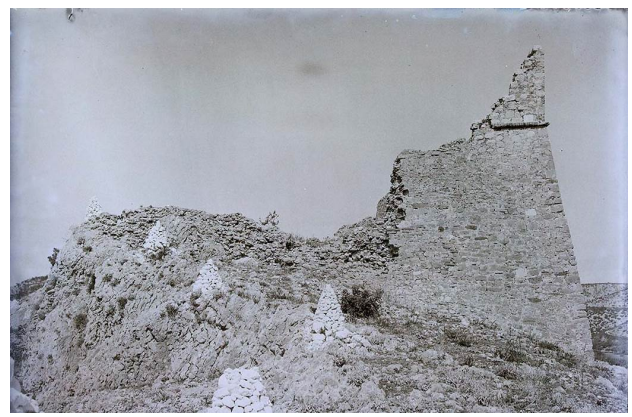

Fig. 6. The remains of Fort Turina, late nineteenth century (Marasović, 2009).

Since 2006, Fort Turina had experienced a series of drastic, arbitrary conservation decisions, which resulted in the "restoration" of the walls, a new vault and terrace, and an external staircase. If any archaeological excavations were made, they were not published or reported on by me- dia. A new conservation study from 2018 recommended the removal of these recent layers and restoration of Fort Turina while respecting the contemporary scientific methods and heritage protection criteria (Sančanin, Suljić, 2018).

The first historical data about the fortifications of Skradin come from early sixteenth century, on a map depicting the Dalmatian hinterland, drawn around 1510 (Barzman, 2014). It shows a town with walls stretching from the coastal tower towards the one on the hill, the last one obviously being Turina. Somewhat less precise and wellknown map published by Matteo Pagano in late 1520 s also shows the town of Skradin encircled by walls.

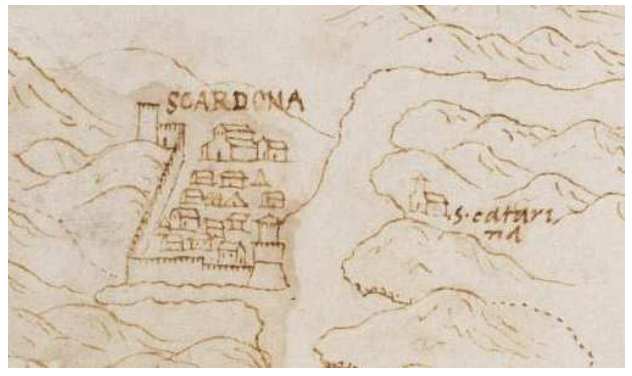

Fig. 7. Skradin around 1510, north is left (Barzman, 2014).

The report about the Venetian-Ottoman war of 1537-40, made about a decade later, describes the short Venetian occupation. The town is circondata di muro ma non forte, but it still has two castelli, and the Venetian commander Camillo Orsini was tasked of selecting one of them and converting it to fortezza. But, at the insistence of people of Šibenik, Skradin was razed and abandoned by Venetians. This may have been the moment when an unknown author made the still unpublished veduta of Skradin. This image almost literally draws the words of sindico Giustiniani -presenting the dominant middle tower (Fort Turina) and the walls which descend towards the seasides.

The 1571 drawing of G. Camocio describes the fort "fortezza altre fiate ruinata". The following text speaks about "notabili rovine di magnifiche e gran fabriche" north of Skradin (Čvrljak, 1995). It's not quite clear whether this could be 
Fort Turina, or some other fortified location in the hinterland. A year later, Dalmatian provveditore generale, Jacopo Foscarini reports that Scardona is "debole senza artellaria spianato ma novamente hanno poca piu alto fabricato un ridotto (marked by J.P.) per esser piu sicuri delle galere" (CRV, tom. IV, 1964, p. 43).

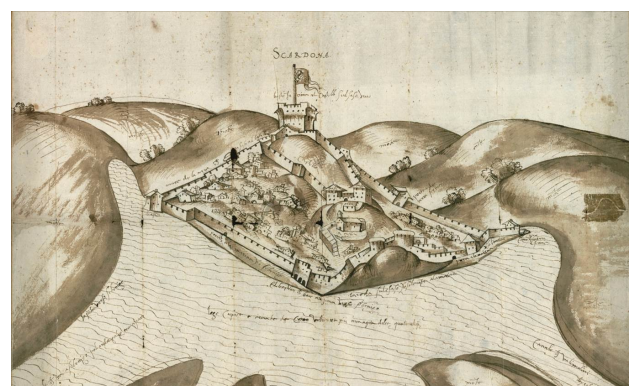

Fig. 8. Veduta of Skradin, early-to-mid sixteenth century, north is up (Archivio di Stato di Venezia [ASVe], Provveditori alle Fortezze, b. 82, dis. 102).

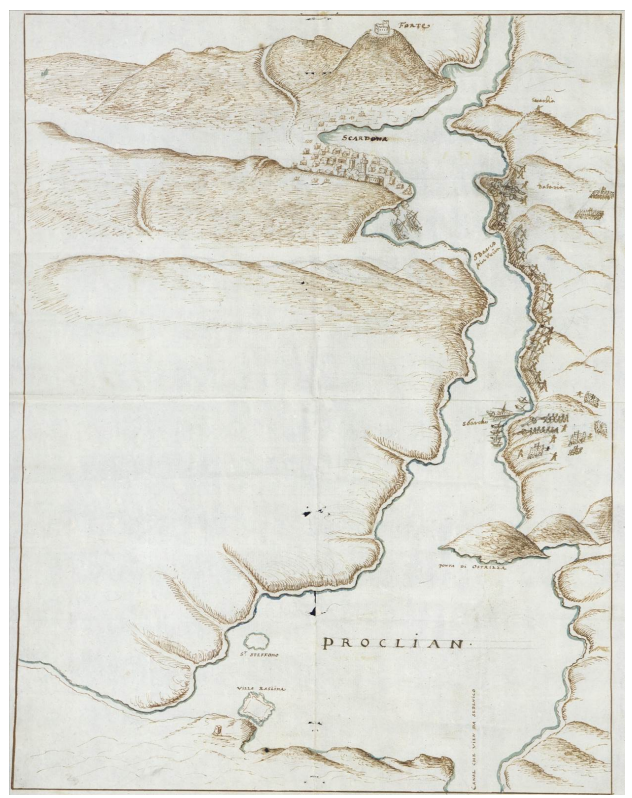

Fig. 9. Venetian assault on Skradin, 1647, north is left (ASVe, Dispacci, Rettori Dalmazia, f. 52, dis. 1).

The next collection of sources, made during the War of Crete, are confirming the claims about another fortification, made by Foscarini more than 70 years ago. Two defensive positions in Skradin are routinely mentioned during the three assaults of Foscolo in 1647 -the main one (castello or fortezza)-, and the smaller one. Foscolo later reports that he destroyed "two forts and mosques of Skradin" (CRV, tom. VII, 1972, p. 69). Two decades later, during the peace negotiations of 1670 , Venetians had again sent their army to Skradin, with "commander Zavoreo being trenched in the town, and colonel Divnić outside on one hill" (Difnik, 1986).

All of these written sources are confirmed by multiple graphic ones, made immediately after the initial 1647 Venetian conquests in Dalmatia. All of them are showing a weakly fortified Skradin between two coves, with the main defensive stronghold, attacked by Venetians, being Castello or Forte on the top of the eastern hill (Slukan Altić, 2007, p. 160).

\section{Conclusion: the second fortification}

Numerous indications which suggest the existence of a dislocated Ottoman fort east of Skradin have not caught the attention of researchers so far. Some remains were allegedly visible in late nineteenth century (Zlatović, 1896). According to the graphic sources, the castello or forte had two square or polygonal towers oriented towards the river, and another larger one inland. The additional confirmation came with the detailed map of Skradin made by engineer Stefano de Boucaut in 1686, with the location and spatial form of the second fortification is clearly visible.

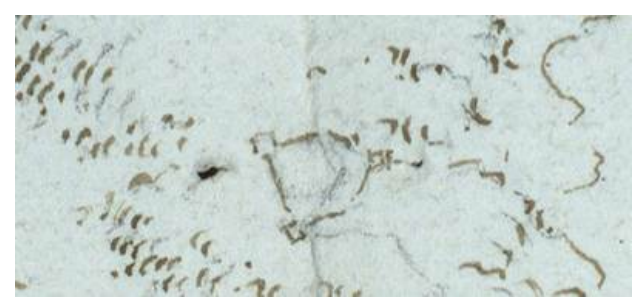

Fig. 10. S. de Boucaut, outline of the Ottoman fort from his 1686 map; north is right (ASVe, Provveditori da Terra e da Mar, f. 526, dis. 1).

There is also a toponymical clue, because the hill east of Skradin was marked with the name "Gradina" (a common rural name for an elevated location with ruins) in the 1827 Austrian cadastral map. 
The first reconnaissance survey was made on October $5^{\text {th }}, 2018$. The terrain on the Gradina hill is covered with vegetation made mostly of Aleppo pines and thick low bushes (maquis). The area is criss-crossed with dry-walled trenches and bunkers, leftovers from the retreat of German army in late phases of World War II. An elevated position was noticed, but the access to it and overall movement on the terrain was limited.

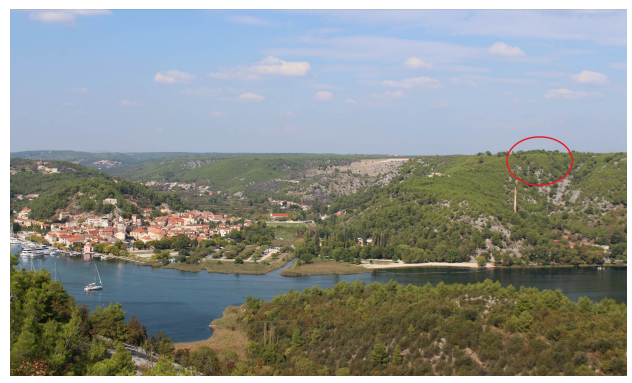

Fig. 11. Location of the Ottoman fort (J. Pavić).

The next survey was made 4 days later, and the aforementioned elevated point was recognized as a south-eastern tower of the Ottoman fort. The cursory ground examination discovered a large stone profile, clearly a part of a door frame, along with fragments of bricks and travertine. A connection towards the curtain wall was also found. The mortar between the stone layers clearly separates these structures from the later dry-walled ones.
More detailed inspection revealed the location of south-western tower, along with some walls going towards the north. Additional works will not be possible before the area is at least partially cleared of vegetation, and the removal of some recent dry-walled structures.

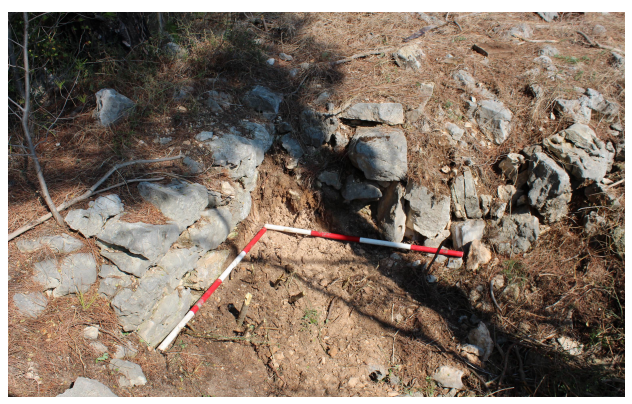

Fig. 11. The corner between the curtain wall and south-eastern tower (A. Nakić).

The Ottoman fort in Skradin was built on the hill east of the town, most likely between 1553 and 1570. It was the seat of dizdar (military commander) and the Ottoman garrison, which could more easily spot the approaching of Venetian galleys from this heightened position. It was destroyed in the early stages of War of Crete and was never rebuilt, as Skradin's military importance decreased. The remains, found in late 2018, their future research and comparison with well-known neighbouring examples (Zadvarje, Vrgorac) could give insight into fortification building on the Ottoman western frontier.

\section{Bibliography}

Babić, I. (1986). Skradin i njegovo područje u prošlosti, Mjesna zajednica Ed., Skradin.

Barzman, K. (2014). "Cartographic Line and the «Paper Management» of the Early Modern State: A Case Study of Venetian Dalmatia”, Mapline, 122. pp. 1-12.

Buzov, S. (2009). "Kad su gospođe Sejdija i Fatima imale mlinove na Krki: o (preko)graničnoj ekonomiji u skradinskoj nahiji", Titius, 2, pp. 27-47.

Čvrljak, K. (1995). Znameniti putnici u Skradinu i na Krki, Poglavarstvo grada Skradina, Hrvatska matica iseljenika, Hrvatski informativni centar, Skradin.

Difnik, F. (1986). Povijest Kandijskog rata u Dalmaciji, Književni krug Ed., Split.

Karbić, D. (2004). "Šubići Bribirski do gubitka nasljedne banske časti (1322.)", Zbornik Odsjeka za povijesne znanosti Zavoda za povijesne i društvene znanosti HAZU, 22, pp. 1-26.

Marasović, J. (2009). Marasović - fotografska zbirka, Javna ustanova Nacionalni park Krka - Gradski muzej Drniš, Šibenik.

Sančanin, M.; Suljić, A. (2018). Konzervatorski elaborat za utvrdu Turina u Skradinu, Zagreb. 
Sanuto M. (1879-1903). I Diarii di Marino Sanuto, Venezia, tom. I-LVIII.

Slukan Altić, M. (2007). Povijesna kartografija rijeke Krke, Javna ustanova Nacionalni park Krka, Šibenik.

Soldo, J.A. (1991). “Skradin pod Venecijom”, Radovi Zavoda za povijesne znanosti HAZU u Zadru, 33, pp. 131-183. Spaho, F.; Aličić A., eds. (2007). Opširni popis Kliškog sandžaka iz 1550. Godine, Orijentalni institut Ed., Sarajevo.

VV.AA. (1876-1977). Commisiones et Relationes Venetae (CRV), Jugoslavenska akademija znanosti i umjetnosti, Zagreb, tom. I-VIII.

Zlatović, S: (1896). "Topografičke crtice o starohrvatskim županijama u Dalmaciji i starim gradovima na kopnu od Velebita do Neretve", Starohrvatska prosvjeta, vol. 2, pp. 87-90. 
